\title{
General synthetic strategy for clavaminols A, C and $H$
}

\author{
Barla Thirupathi, Yada Bharath, and Debendra K. Mohapatra* \\ Natural Products Chemistry Division, CSIR-Indian Institute of Chemical Technology \\ Hyderabad-500607, India \\ E-mail:mohapatra@iict.res.in
}

Dedicated to Dr. J. S. Yadav on the occasion of his 65 th birthday and in appreciation of his outstanding contributions to synthetic organic chemistry

DOI: http://dx.doi.org/10.3998/ark.5550190.p009.281

\begin{abstract}
A general and efficient synthetic strategy has been developed for the total syntheses of clavaminols $\mathrm{A}, \mathrm{C}$ and $\mathrm{H}$ in 5 to 7 steps starting from $(R)$-Garners aldehyde following Grignard reaction, Corey-Bakshi-Shibata asymmetric reduction and selective acetylation as key steps with 42 to $59 \%$ overall yields, respectively.
\end{abstract}

Keywords: Clavaminols, sphingosine, cytotoxic, Garners aldehyde, CBS asymmetric reduction

\section{Introduction}

The marine natural products have played leading role for anticancer drug discovery. More than $70 \%$ of the drugs are now in clinical trials for cancer patients, either natural products or pharmacophore designed from the natural products. ${ }^{1,2}$ A thorough investigation of the chemical constituents of the Mediterranean ascidian Clavelina phlegraea led to the isolation of clavaminols A-N which are new marine sphingoid-type compounds. ${ }^{3,4}$ The structures of these molecules are generally related to the widely distributed amphiphilic sphingosine related long chain amino alcohols, ${ }^{5-7}$ the central structural element of sphingolipids; their carbon chain varies from $\mathrm{C}_{12}$ to $\mathrm{C}_{30}$ and few of them have also polyunsaturated variants. ${ }^{8-12}$ Their structures were established by thorough analysis of spectroscopic data and chemical conversion. These compounds showed cytotoxic and pro-apoptotic activities against different cell lines A549 (lung carcinoma), T47D (breast carcinoma) and AGS (gastric carcinoma), including cell death through activation of the apoptotic machinery. Among them clavaminol A (Figure 1) had shown more cytotoxic activity with $\mathrm{IC}_{50}$ near $5 \mu \mathrm{g} / \mathrm{mL}$. Structurally, the 2-amino-3-alkanols isolated from Clavelina phlegraea were found to have $(2 R, 3 S)$-configuration, which is opposite to that of the 
well-known sphingolipids or other 2-amino-3-alkanols such as $(2 S, 3 R)$-2-aminododecan-3-ol, ${ }^{13}$ an antifungal agent (against Candida albicans with MIC $30 \mu \mathrm{g} / \mathrm{mL}$ ) isolated from Clavelina oblonga and (2S,3R)-2-aminotetradecan-3-ol, an inhibitor of cell proliferation isolated from Spisula polynima. ${ }^{14-16}$ Synthesis and complete biological profile of $(2 S, 3 R)$-2-aminodecanols was well reported in literature. ${ }^{17-20}$

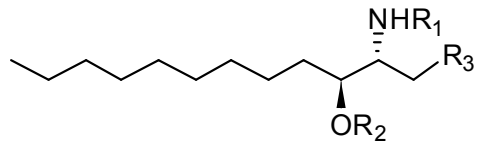

1. $\mathrm{R}_{1}=\mathrm{H} ; \mathrm{R}_{2}=\mathrm{H} ; \mathrm{R}_{3}=\mathrm{H}$; Clavaminol A

2. $\mathrm{R}_{1}=\mathrm{Ac} ; \mathrm{R}_{2}=\mathrm{H} ; \mathrm{R}_{3}=\mathrm{H}$; Clavaminol $\mathrm{C}$

3. $\mathrm{R}_{1}=\mathrm{H} ; \mathrm{R}_{2}=\mathrm{Ac} ; \mathrm{R}_{3}=\mathrm{H}$; Clavaminol $\mathrm{F}$

4. $\mathrm{R}_{1}=\mathrm{Ac} ; \mathrm{R}_{2}=\mathrm{Ac} ; \mathrm{R}_{3}=\mathrm{H}$; Clavaminol I

5. $\mathrm{R}_{1}=\mathrm{Ac} ; \mathrm{R}_{2}=\mathrm{H} ; \mathrm{R}_{3}=\mathrm{OH} ;$ Clavaminol $\mathrm{H}$

6. $\mathrm{R}_{1}=\mathrm{CHO} ; \mathrm{R}_{2}=\mathrm{H} ; \mathrm{R}_{3}=\mathrm{H}$; Clavaminol $\mathrm{L}$

7. Clavaminol D

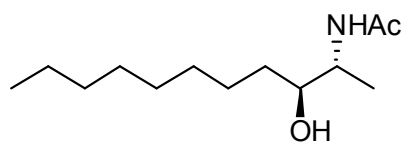

Figure 1: Structures of clavaminols.

\section{Results and Discussion}

These molecules are mostly long chain amino alcohols and their potent biological activity which ranges from antimicrobial activity to inhibition of cell proliferation through prevention of the formation of actin stress fibers in cultured cells, ${ }^{21-29}$ attracted many natural products chemists. There are very few protocols reported for the synthesis of clavaminols. The first total synthesis of clavaminol A, C and $\mathrm{H}$ was achieved by Andrew Sutherland et al., ${ }^{30}$ starting from $(R)$-glycidol with an overall yield of $29 \%$ and confirmed absolute configuration as $(2 R, 3 S)$. An improved four step synthesis of long-chain anti-2-amino-3-alkanols was achieved by Huang and co-workers. ${ }^{31}$ In this context, we have thought of developing a general synthetic approach for the synthesis of all 2-amino-3-alakanols. Herein, we report the synthesis of clavaminols A, C and $\mathrm{H}$ from commercially available Garners aldehyde ${ }^{32,33}$ in concise and high overall yields.
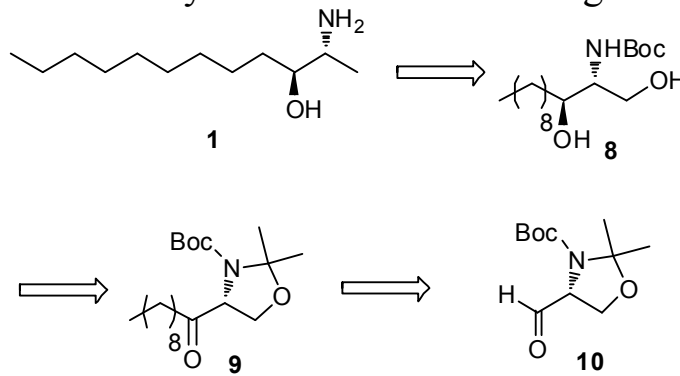

Scheme 1. Retrosynthetic analysis. 
In our retrosynthetic perspective, we envisaged that the target molecules could be achieved from compound $\mathbf{8}$, serving as the key intermediate in the present synthesis. The hydroxyl group at $\mathrm{C} 3$ of the natural products was planned to be introduced by diastereoselective nucleophilic addition on Garners aldehyde or by oxidation followed by asymmetric reduction using CoreyBakshi-Shibata catalyst (Scheme 1).
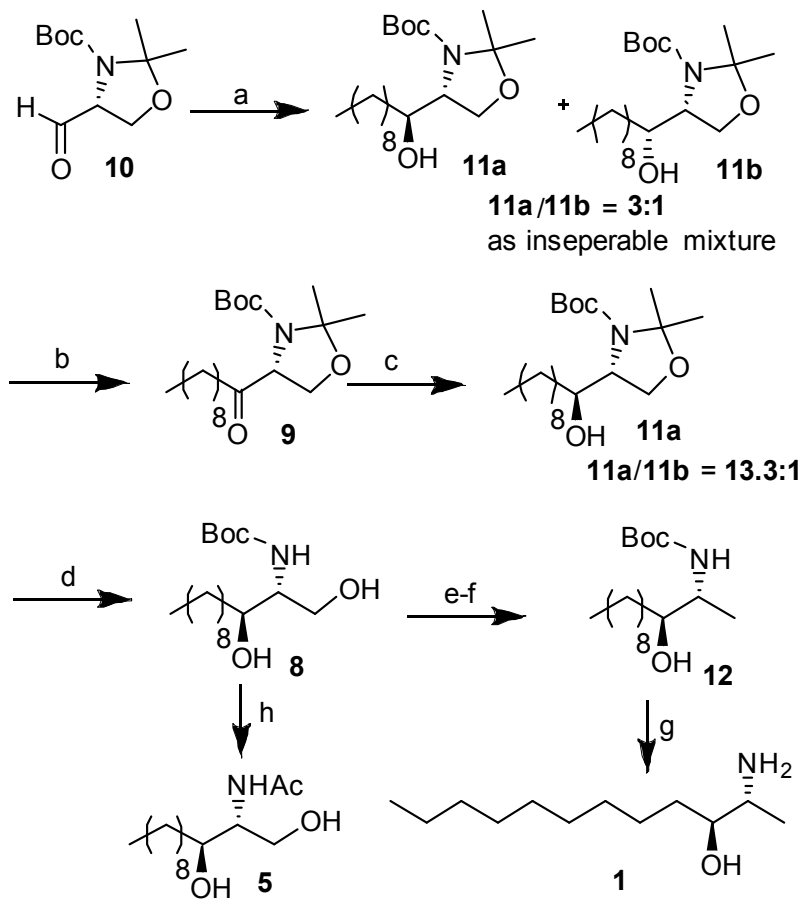

Scheme 2: Synthesis of clavaminols $\mathrm{A}$ (1) and $\mathrm{H}$ (5): Reagents and conditions: (a) Nonylmagnesium bromide, THF, $-78{ }^{\circ} \mathrm{C}-0{ }^{\circ} \mathrm{C}, 30 \mathrm{~min}, 91 \%$, (syn/anti = 1:3); (b) DMP, $\mathrm{CH}_{2} \mathrm{Cl}_{2}$, $0{ }^{\circ} \mathrm{C}-\mathrm{rt}, 30 \mathrm{~min}, 96 \%$; (c) (R)-CBS, THF, $-40{ }^{\circ} \mathrm{C}, 8 \mathrm{~h}, 92 \%$; (d) $\mathrm{CSA}, \mathrm{MeOH}, 0{ }^{\circ} \mathrm{C}-\mathrm{rt}, 4 \mathrm{~h}, 90 \%$; (e) $\mathrm{TsCl}, \mathrm{Et}_{3} \mathrm{~N}, \mathrm{CH}_{2} \mathrm{Cl}_{2}, 0{ }^{\circ} \mathrm{C}$-rt, $5 \mathrm{~h}$; (f) $\mathrm{LiAlH}_{4}, \mathrm{THF},-20{ }^{\circ} \mathrm{C}, 4 \mathrm{~h}, 79 \%$ over two steps; (g) $\mathrm{Et}_{2} \mathrm{O}-$ $\mathrm{HCl}, 0{ }^{\circ} \mathrm{C}$-rt 10 h, 88\%; (h) (1) TFA, $\mathrm{CH}_{2} \mathrm{Cl}_{2}-\mathrm{H}_{2} \mathrm{O}, 0{ }^{\circ} \mathrm{C}$-rt, $2 \mathrm{~h}$; (2) $\mathrm{AcCl}, \mathrm{NaHCO}_{3}, \mathrm{CH}_{2} \mathrm{Cl}_{2}-\mathrm{H}_{2} \mathrm{O}$ $(1: 1), 0{ }^{\circ} \mathrm{C}-\mathrm{rt}, 3 \mathrm{~h}, 85 \%$ (over two steps).

Accordingly, our synthesis was started from commercially available $(R)$-Garners aldehyde (10). Stereoselective addition of freshly prepared nonylmagnesium bromide on Garners aldehyde at $-78{ }^{\circ} \mathrm{C}$ gave syn and anti in the ratio 1:3 (By HPLC). ${ }^{34}$ The hydroxyl group present in compound 11 was smoothly converted to ketone 9 by using Dess-Martin periodinane (DMP) (Scheme 2). ${ }^{35,36}$ Stereoselective reduction of keto group was then undertaken. Here, we have screened different chelation controlled reducing agents to get good anti selectivity. ${ }^{34}$ Among them $(R$ )-CBS reductions gave good selectivity in 93:7 ratio (by HPLC) with 92\% yield (Table 1). The acetonide group present in 11a was then deprotected with CSA in methanol to afford 8 with $90 \%$ yield. 


\section{Table1. Chelation controlled reduction}<smiles>CC(C)(C)OC(=O)N1[C@H](C(=O)OC(=O)C(C)(C)C)COC1(C)C</smiles>

9

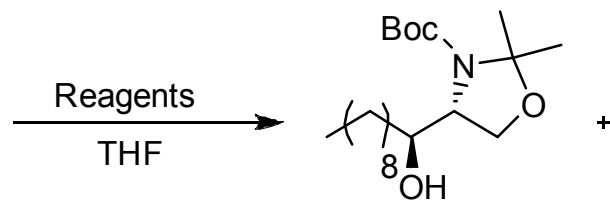

$11 \mathrm{a}$<smiles>CC(C)(C)C(=O)OC(=O)C1COC(C)(C)N1C(=O)O</smiles>

11b

\begin{tabular}{lllll}
\hline Entry & Reagent $^{\mathrm{a}}$ & $\begin{array}{l}\text { Time } \\
(\mathrm{h})\end{array}$ & $\begin{array}{l}\text { Yield } \\
(\%)\end{array}$ & $\begin{array}{l}\text { Ratio } \\
\text { anti/syn }\end{array}$ \\
\hline 1 & $\mathrm{ZnBH}_{4}$ & 3 & 94 & $80: 20$ \\
2 & $\mathrm{NaBH}_{4}$ & 2 & 89 & $65: 35$ \\
3 & $\mathrm{~K}-\mathrm{Selectride}$ & 4 & 85 & $70: 30$ \\
4 & $(R)-\mathrm{CBS}$ & 5 & 92 & $93: 07$ \\
\hline
\end{tabular}

${ }^{\mathrm{a}}$ The reaction was conducted under anhydrous and inert conditions.

Compound 8 was converted to compound 12 in two steps. In the first step, primary alcohol was selectively protected as tosylate, ${ }^{37}$ followed by replacement of tosyl group with hydride in presence of $\mathrm{LiAlH}_{4}{ }^{38}$ afforded desired compound 12. Deprotection of Boc group with $\mathrm{HCl}$ in ether afforded clavaminol A (1) in 88\% yield. From intermediate 8, clavaminol H (5) was prepared in situ, Boc-deprotection with TFA followed by selective $N$-acylation in presence of hydroxyl group with acetyl chloride in $\mathrm{CH}_{2} \mathrm{Cl}_{2}-\mathrm{H}_{2} \mathrm{O}$ (1:1) with $85 \%$ yield. ${ }^{39}$ Similarly, Clavaminol C (2) was prepared from 1 under the same reaction conditions as followed for the preparation of 5 from $\mathbf{8}$ (Scheme 3).

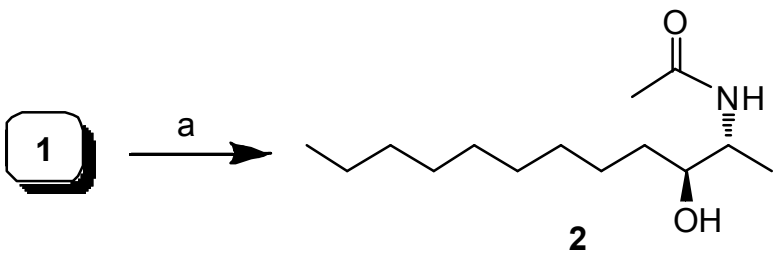

Scheme 3. Synthesis of clavaminols C (2) from clavaminol A (1): Reagents and conditions: (a) $\mathrm{AcCl}, \mathrm{NaHCO}_{3}, \mathrm{CH}_{2} \mathrm{Cl}_{2}-\mathrm{H}_{2} \mathrm{O}(1: 1), 0{ }^{\circ} \mathrm{C}-\mathrm{rt}, 3 \mathrm{~h}, 89 \%$.

\section{Conclusions}

The total synthesis of clavaminols $\mathrm{A}, \mathrm{C}$ and $\mathrm{H}$ were achieved in an efficient manner starting from commercially available $(R)$-Garner's aldehyde in 5 to 7 steps with 42 to $59 \%$ overall yields, respectively. The key steps of the synthesis are Grignard reaction, chelation-controlled reduction 
and selective acetylation reactions. Our protocol is highly general and flexible for the synthesis of other related natural products compared with earlier reports.

\section{Experimental Section}

General. All reactions were carried out under inert atmosphere, unless otherwise mentioned. Solvents were dried and purified by standard methods prior to use. The progress of all reactions was monitored by TLC using glass plates precoated with silica gel 60 F254 to a thickness of 0.5 $\mathrm{mm}$. Column chromatography was performed on silica gel (60 mesh) using ethyl acetate and hexane as the eluents. Optical rotations were measured with Perkin Elmer P241 polarimeter and JASCO DIP-360 digital polarimeter at $27{ }^{\circ} \mathrm{C}$. IR spectra were recorded on a Perkin-Elmer FT-IR spectrometer. ${ }^{1} \mathrm{H}$ and ${ }^{13} \mathrm{C}$ NMR spectra were recorded on a Variant Gemini $200 \mathrm{MHz}$, Bruker Avance $300 \mathrm{MHz}$, or Varian Inova $500 \mathrm{MHz}$ spectrometer using TMS as an internal standard in $\mathrm{CDCl}_{3}, \mathrm{CD}_{3} \mathrm{OD}$ etc. Mass spectra were on Micromass VG-7070H for EI.

(R)-tert-Butyl 4-(1-hydroxydecyl)-2,2-dimethyloxazolidine-3-carboxylate (11). To a stirred solution of Garner's aldehyde $\mathbf{1 0}(6.0 \mathrm{~g}, 26.20 \mathrm{mmol})$ in anhydrous THF $(100 \mathrm{~mL})$ was added freshly prepared nonylmagnesium bromide $(61 \mathrm{~mL}, 0.52 \mathrm{M})$ at $-78{ }^{\circ} \mathrm{C}$ under nitrogen atmosphere. The reaction mixture was stirred for $1 \mathrm{~h}$ at $-78^{\circ} \mathrm{C}$ when TLC showed completion of the reaction. The reaction mixture was quenched with saturated aqueous ammonium chloride (50 $\mathrm{mL})$, extracted with ethyl acetate $(3 \times 100 \mathrm{~mL})$. The combined organic layers were washed with brine $(150 \mathrm{~mL})$, dried over $\mathrm{Na}_{2} \mathrm{SO}_{4}$ and concentrated under reduced pressure. The crude product was purified by silica gel column chromatography (ethyl acetate/hexane 1:5) to furnish the desired compound $11(8.5 \mathrm{~g}, 91 \%)$ as a colorless liquid. $[\alpha]_{\mathrm{D}}{ }^{27}+22.4\left(c 1.1, \mathrm{CHCl}_{3}\right)$; IR (neat): 3451, 2926, 2855, 1700, 1391, 1255, 1174, $1066 \mathrm{~cm}^{-1}$; ${ }^{1} \mathrm{H}$ NMR (300 MHz, $\left.\mathrm{CDCl}_{3}\right): \delta 4.18-3.48$ $(\mathrm{m}, 4 \mathrm{H}), 1.62-1.53(\mathrm{~m}, 3 \mathrm{H}), 1.49(\mathrm{~s}, 12 \mathrm{H}), 1.28(\mathrm{~s}, 10 \mathrm{H}), 0.89(\mathrm{t}, J 7.0 \mathrm{~Hz}, 3 \mathrm{H}) \mathrm{ppm} ;{ }^{13} \mathrm{C} \mathrm{NMR}$ (75 MHz, $\mathrm{CDCl}_{3}$ ): 153.9, 93.9, 80.6, 72.3, 64.3, 62.1, 32.8, 31.7, 29.5, 29.1, 28.1, 26.3, 25.9, 25.2, 24.1, 22.4, 13.9 ppm; HRMS (ESI) $m / z$ calcd. for $\mathrm{C}_{20} \mathrm{H}_{39} \mathrm{NO}_{4}[\mathrm{M}+\mathrm{Na}]^{+} 380.27709$, found 380.27713 .

(R)-tert-Butyl 4-decanoyl-2,2-dimethyloxazolidine-3-carboxylate (9). To a stirred solution of alcohol 11 (5.1 g, $14.28 \mathrm{mmol})$ in anhydrous $\mathrm{CH}_{2} \mathrm{Cl}_{2}(50 \mathrm{~mL})$ was added Dess-Martin periodinane $(1.76 \mathrm{~g}, 28.56 \mathrm{mmol})$ at $0{ }^{\circ} \mathrm{C}$ under nitrogen atmosphere. After completion of the reaction (monitored by TLC), it was filtered through a Celite bed and washed thoroughly with $\mathrm{CH}_{2} \mathrm{Cl}_{2}(2 \times 50 \mathrm{~mL})$. The filtrate was washed with sodium thiosulphate $(2 \times 100 \mathrm{~mL})$, then brine $(2 \times 100 \mathrm{~mL})$ and dried over anhydrous $\mathrm{Na}_{2} \mathrm{SO}_{4}$, concentrated under reduced pressure. The crude product was purified by silica gel column chromatography (ethyl acetate/hexane 1:10) to furnish the desired compound $9(4.8 \mathrm{~g}, 96 \%)$ as light yellow oil. $[\alpha]_{\mathrm{D}}{ }^{27}+17.6\left(c 1.0, \mathrm{CHCl}_{3}\right)$; IR (neat): 2927, 2856, 1708,1461, 1372, 1266, 1172, 1094, $850 \mathrm{~cm}^{-1} ;{ }^{1} \mathrm{H}$ NMR (300 MHz, $\left.\mathrm{CDCl}_{3}\right): \delta 4.44$ $(\mathrm{dd}, J 2.3,6.8 \mathrm{~Hz}, 1 \mathrm{H}), 4.32(\mathrm{dd}, J 2.3,7.5 \mathrm{~Hz}, 1 \mathrm{H}), 4.14\left(\mathrm{AB}_{\mathrm{q}}, J 9.1,17.4 \mathrm{~Hz}, 1 \mathrm{H}\right), 3.90$ (ddd, $J$ 2.3, 3.0, $12.1 \mathrm{~Hz}, 1 \mathrm{H}), 2.54-2.45(\mathrm{~m}, 2 \mathrm{H}), 1.62-1.56(\mathrm{~m}, 3 \mathrm{H}), 1.50(\mathrm{~s}, 9 \mathrm{H}), 1.26(\mathrm{~s}, 16 \mathrm{H}), 0.88(\mathrm{t}$, 
$J 6.8 \mathrm{~Hz}, 3 \mathrm{H}) \mathrm{ppm} ;{ }^{13} \mathrm{C} \mathrm{NMR}\left(75 \mathrm{MHz}, \mathrm{CDCl}_{3}\right): 208.0,151.0,94.7,80.0,65.3,64.9,38.1,31.5$, 29.0, 27.9, 24.9, 23.3, 22.3, 13.7 ppm; HRMS (ESI) $\mathrm{m} / z$ calcd. for $\mathrm{C}_{20} \mathrm{H}_{37} \mathrm{NO}_{4}[\mathrm{M}+\mathrm{Na}]^{+}$ 378.26151, found 378.26148.

(R)-tert-Butyl 4-((S)-hydroxydecyl)-2,2-dimethyloxazolidine-3-carboxylate (11a). To a stirred solution of $(R)$-CBS catalyst was added $\mathrm{BH}_{3}$-DMS $(7.2 \mathrm{~mL}, 1 \mathrm{M})$ at $-40{ }^{\circ} \mathrm{C}$ and stirred it for $45 \mathrm{~min}$ at same temperature. The solution of ketone $9(2.5 \mathrm{~g}, 7.04 \mathrm{mmol})$ in THF $(10 \mathrm{~mL})$ was added to the reaction mixture and it was allowed to stir for $8 \mathrm{~h}$ at $-40{ }^{\circ} \mathrm{C}$. TLC showed completion of the reaction. The reaction mixture was quenched with methanol $(10 \mathrm{~mL})$ and concentrated under reduced pressure. The crude product was purified by silica gel column chromatography (ethyl acetate/hexane 1:5) to furnish the desired compound 11a $(2.3 \mathrm{~g}, 92 \%)$ as a colorless liquid. $[\alpha]_{\mathrm{D}}{ }^{27}+10.2\left(c\right.$ 2.5, $\left.\mathrm{CHCl}_{3}\right)$; IR (neat): 3355, 2923, 2923, 1689, 1533, 1465, $1175,1053 \mathrm{~cm}^{-1}$; ${ }^{1} \mathrm{H}$ NMR $\left(300 \mathrm{MHz}, \mathrm{CDCl}_{3}\right): \delta 4.12-3.53(\mathrm{~m}, 4 \mathrm{H}), 1.59(\mathrm{~s}, 4 \mathrm{H}), 1.50(\mathrm{~s}, 12 \mathrm{H})$, $1.26(\mathrm{~s}, 15 \mathrm{H}), 0.88(\mathrm{t}, J 6.0 \mathrm{~Hz}, 3 \mathrm{H}) \mathrm{ppm} ;{ }^{13} \mathrm{C} \mathrm{NMR}\left(75 \mathrm{MHz}, \mathrm{CDCl}_{3}\right): 151.3,95.0,80.4,65.6$, $65.2,38.4,31.8,29.6,29.2,28.2,26.1,25.3,24.7,23.6,23.0,22.6,14.0$ ppm; HRMS (ESI) $\mathrm{m} / \mathrm{z}$ calcd. for $\mathrm{C}_{20} \mathrm{H}_{40} \mathrm{NO}_{4}[\mathrm{M}+\mathrm{H}]^{+} 358.29558$, found 358.29519.

tert-Butyl-(2R,3S)-1,3-dihydroxydodecan-2-yl-carbamate (8). To a stirred solution of compound $11 \mathrm{a}(2.1 \mathrm{~g}, 5.88 \mathrm{mmol})$ is $\mathrm{CH}_{2} \mathrm{Cl}_{2}(30 \mathrm{~mL})$ added $\mathrm{CSA}$ (catalytic amount) at $0{ }^{\circ} \mathrm{C}$ stirred for $1 \mathrm{~h}$ at room temperature. After completion of the reaction (monitored by TLC), it was quenched with triethylamine and concentrated under reduced pressure. The crude product was purified by silica gel (ethyl acetate/hexane 1:5) to furnish the desired compound 8 (2.0 g, 90\%) as a colorless liquid. $[\alpha]_{\mathrm{D}}{ }^{27}-3.5\left(c 1.3, \mathrm{CHCl}_{3}\right)$; IR (neat): $3350,2925,2854,1688,1258,1366$, 1174, $1051 \mathrm{~cm}^{-1}$; ${ }^{1} \mathrm{H}$ NMR $\left(300 \mathrm{MHz}, \mathrm{CDCl}_{3}\right): \delta 5.43$ (d, J $\left.7.5 \mathrm{~Hz}, 1 \mathrm{H}\right), 3.98$ (dd, $J 3.0,10.6 \mathrm{~Hz}$, $1 \mathrm{H}), 3.74-3.68(\mathrm{~m}, 2 \mathrm{H}), 2.80\left(\mathrm{AB}_{\mathrm{q}}, J 3.0,27.5 \mathrm{~Hz}, 2 \mathrm{H}\right), 1.83($ br s, $1 \mathrm{H}), 1.44(\mathrm{~s}, 9 \mathrm{H}), 1.27(\mathrm{~s}$, $14 \mathrm{H}), 0.88$ (t, $J 6.0 \mathrm{~Hz}, 3 \mathrm{H}) \mathrm{ppm} ;{ }^{13} \mathrm{C} \mathrm{NMR}\left(75 \mathrm{MHz}, \mathrm{CDCl}_{3}\right): 156.1,79.6,74.0,62.4,54.8$, 34.3, 34.1, 31.8, 29.5 29.3, 28.3, 25.9, 25.6, 22.6, $14.0 \mathrm{ppm}$; HRMS (ESI) $\mathrm{m} / \mathrm{z}$ calcd. for $\mathrm{C}_{17} \mathrm{H}_{36} \mathrm{NO}_{4}[\mathrm{M}+\mathrm{H}]^{+} 318.26428$, found 318.26389.

tert-Butyl-(2R,3S)-3-hydroxydodecan-2-ylcarbamate (12). To a stirred solution of 1,3-diol 8 $(2.0 \mathrm{~g}, 6.30 \mathrm{mmol})$ in $\mathrm{CH}_{2} \mathrm{Cl}_{2}(30 \mathrm{~mL})$, was added triethyl amine $(1.63 \mathrm{~mL}, 12.63 \mathrm{mmol})$ at $0{ }^{\circ} \mathrm{C}$ followed by tosyl chloride $(1.38 \mathrm{~g}, 6.94 \mathrm{mmol})$ and catalytic amount of dibutyltinoxide. The mixture was stirred for $4 \mathrm{~h}$ at room temperature after completion (monitored by TLC), it was quenched with water $(10 \mathrm{~mL})$. The organic layer was separated and the aqueous layer extracted with $\mathrm{CH}_{2} \mathrm{Cl}_{2}(3 \times 25 \mathrm{~mL})$. The combined organic layer was washed with brine $(50 \mathrm{~mL})$, dried over $\mathrm{Na}_{2} \mathrm{SO}_{4}$ and concentrated under reduced pressure. The crude product was purified by silica gel column chromatography (ethyl acetate/hexane 1:5) to furnish the desired compound was immediately used next reaction.

To a slurry of $\mathrm{LiAlH}_{4}(0.41 \mathrm{~g}, 10.7 \mathrm{mmol})$ THF $(10 \mathrm{~mL})$, was added tosylated compound $(2.52$ g, $5.35 \mathrm{mmol})$ in THF $(5 \mathrm{~mL})$ at $-20{ }^{\circ} \mathrm{C}$ and stirred for $5 \mathrm{~h}$ at same temperature. After completion of the reaction (monitored by TLC), it was quenched with saturated aqueous ammonium chloride solution $(20 \mathrm{~mL})$ and filtered through a Celite pad. It was thoroughly washed with ethyl acetate $(2 \times 20 \mathrm{~mL})$. The organic layer was separated and the aqueous layer extracted with ethyl acetate 
( 3 x $40 \mathrm{~mL}$ ). The combined organic layers were dried over $\mathrm{Na}_{2} \mathrm{SO}_{4}$ and concentrated under reduced pressure. The crude product was purified by silica gel (ethyl acetate/hexane 1:5) to furnish the desired compound $12\left(1.33 \mathrm{~g}, 79 \%\right.$ over two steps) $[\alpha]_{\mathrm{D}}{ }^{27}+2.7\left(c \quad 1.2, \mathrm{CHCl}_{3}\right)$; IR (Neat): 3438, 2926, 2855, 1689, 1504, $1032 \mathrm{~cm}^{-1} ;{ }^{1} \mathrm{H}$ NMR (300 MHz, $\left.\mathrm{CDCl}_{3}\right): \delta 4.79\left(\mathrm{AB}_{\mathrm{q}}, J\right.$ 8.3, $24.9 \mathrm{~Hz}, 1 \mathrm{H}), 3.64(\mathrm{~m}, 2 \mathrm{H}), 3.48$ (br s, 1H), 2.30 (br s, 1H), 1.44 (s, 9H), $1.26(\mathrm{~s}, 13 \mathrm{H})$, $1.17(\mathrm{~d}, J 6.8 \mathrm{~Hz}, 3 \mathrm{H}), 0.88(\mathrm{t}, J 6.0 \mathrm{~Hz}, 3 \mathrm{H}) \mathrm{ppm} ;{ }^{13} \mathrm{C} \mathrm{NMR}\left(75 \mathrm{MHz}, \mathrm{CDCl}_{3}\right): 156.2,74.8$, 74.3, 50.2, 34.1, 33.4, 32.7, 31.8, 29.6, 29.2, 28.3, 26.0, 25.6, 22.6, 14.1 ppm; HRMS (ESI) $\mathrm{m} / \mathrm{z}$ calcd. for $\mathrm{C}_{17} \mathrm{H}_{35} \mathrm{NO}_{3}[\mathrm{M}]^{+} 301.26174$, found 301.26148.

(2R, 3S)-2-Aminododecan-3-ol (Clavaminol A) (1). $\mathrm{HCl}$ ether $(6.6 \mathrm{~mL}, 6.63 \mathrm{mmol}, 1 \mathrm{M})$ was added compound $12(0.5 \mathrm{~g}, 1.66 \mathrm{mmol})$ at $0{ }^{\circ} \mathrm{C}$ and stirred for $2 \mathrm{~h}$ at room temperature. After completion of the reaction (monitored by TLC), the solvent was evaporated under reduced pressure and the resulting oil dissolved in ethyl acetate $(20 \mathrm{~mL})$. Aqueous ammonia solution (10 $\mathrm{mL}$ ) was added at $0{ }^{\circ} \mathrm{C}$ and the organic layer was separated. The aqueous layer was extracted with ethyl acetate $(3 \times 15 \mathrm{~mL})$. The combined organic layer was washed with $\mathrm{NaHCO}_{3}(40 \mathrm{~mL})$, dried over $\mathrm{Na}_{2} \mathrm{SO}_{4}$ and concentrated under reduced pressure. The crude product was purified by silica gel column chromatography $\left(\mathrm{MeOH} / \mathrm{CH}_{2} \mathrm{Cl}_{2} 1: 10\right)$ to yield $1(0.29 \mathrm{~g}, 88 \%)$ as a white amorphous solid. mp $107-108^{\circ} \mathrm{C}$; $[\alpha]_{\mathrm{D}}{ }^{27}-4.4$ (c 1.2, $\left.\mathrm{MeOH}\right)$; IR (KBr): 3395, 2925, 2854, 1608 , 1500, 1152, 1028, $723 \mathrm{~cm}^{-1}$; ${ }^{1} \mathrm{H}$ NMR (300 MHz, CD $3 \mathrm{OD}$ ): $\delta 3.68-3.74$ (br m, 1H), 3.30-3.24 (br m, 1H), 1.65-1.28 (m, 16H), $1.22(\mathrm{~d}, J 5.9 \mathrm{~Hz}, 3 \mathrm{H}), 0.90(\mathrm{t}, J 7.8 \mathrm{~Hz}, 3 \mathrm{H}) \mathrm{ppm} ;{ }^{13} \mathrm{C}$ NMR $(75$ $\mathrm{MHz}, \mathrm{CDCl}_{3}$ ): 71.6, 52.6, 34.1, 33.1, 30.7, 30.6, 30.5, 27.0, 23.8, 14.5, 12.1 ppm; HRMS (ESI) $m / z$ calcd. for $\mathrm{C}_{12} \mathrm{H}_{28} \mathrm{NO}[\mathrm{M}+\mathrm{H}]^{+}$202.21654, found: 202.21631 .

$N$-((2R,3S)-1,3-Dihydroxydodecan-2-yl)acetamide (clavaminol H) (5). A solution of TFA $/ \mathrm{H}_{2} \mathrm{O}(3.1 \mathrm{~mL}, 0.31 \mathrm{mmol})$ was added to $8(100 \mathrm{mg}, 0.31 \mathrm{mmol})$ in $\mathrm{CH}_{2} \mathrm{Cl}_{2}(5 \mathrm{~mL})$ and the resulting mixture stirred at room temperature for $3 \mathrm{~h}$. After completion of the reaction (as determined by TLC), the solvent was evaporated under reduced pressure and the resulting reddish oil dissolved in ethyl acetate $(10 \mathrm{~mL})$. The organic phase was washed with $\mathrm{NaHCO}_{3}$, dried over $\mathrm{Na}_{2} \mathrm{SO}_{4}$ and concentrated under reduced pressure. The red oil $(0.05 \mathrm{~g}, 0.24 \mathrm{mmol})$ so obtained was dissolved in $\mathrm{CH}_{2} \mathrm{Cl}_{2}-\mathrm{H}_{2} \mathrm{O}(1: 1)(10 \mathrm{~mL})$ and $\mathrm{NaHCO}_{3}(204 \mathrm{mg}, 2.4 \mathrm{mmol})$ was added followed by acetyl chloride $(0.02 \mathrm{~mL}, 0.29 \mathrm{mmol})$. After completion of reaction (monitored by TLC), water $(5 \mathrm{~mL})$ was added to it. The organic layer was separated and the aqueous layer extracted with $\mathrm{CH}_{2} \mathrm{Cl}_{2}(3 \times 20 \mathrm{~mL})$. The combined organic layer dried over $\mathrm{Na}_{2} \mathrm{SO}_{4}$ and concentrated under reduced pressure. The crude product was purified by silica gel column chromatography (ethyl acetate/hexane 1:6) to furnish the desired compound $\mathbf{5}$ (85\% over two steps) as a white amorphous solid. mp $108-110{ }^{\circ} \mathrm{C} ;[\alpha]_{\mathrm{D}}{ }^{27}+3.1(c 1.0, \mathrm{MeOH})$; IR $(\mathrm{KBr})$ : 3294, 2919, 2851, 1649, 1551, 1373, 1090, $1046 \mathrm{~cm}^{-1} ;{ }^{1} \mathrm{H}$ NMR $\left(300 \mathrm{MHz}, \mathrm{CDCl}_{3}\right): \delta 6.58(\mathrm{br}$ d, J 7.5 Hz, 1H), 3.98 (dd, J 3.0, 11.3 Hz, 1H), 3.87-3.70 (m, 3H), 3.13 (br s, 1H), 2.04 (s, 3H), $1.59-1.43(\mathrm{~m}, 2 \mathrm{H}), 1.38-1.21(\mathrm{~m}, 14 \mathrm{H}), 0.88(\mathrm{t}, J 6.0 \mathrm{~Hz}, 3 \mathrm{H})$ ppm; ${ }^{13} \mathrm{C} \mathrm{NMR}(75 \mathrm{MHz}$, $\mathrm{CDCl}_{3}$ ): 170.7, 73.9, 62.2, 53.9, 34.4, 31.8, 29.7, 29.5, 29.3, 26.0, 23.4, 22.6, 14.1 ppm; HRMS (ESI) $m / z$ calcd. for $\mathrm{C}_{14} \mathrm{H}_{29} \mathrm{NO}_{3} \mathrm{Na}[\mathrm{M}+\mathrm{Na}]^{+}$282.20369, found 282.20396. 
$\mathrm{N}-((2 R, 3 S)-3-H y d r o x y d o d e c a n-2-y l)$ acetamide (Clavaminol C) (2). To a stirred solution of compound 1 (0.05 g, $0.24 \mathrm{mmol})$ in $\mathrm{CH}_{2} \mathrm{Cl}_{2}-\mathrm{H}_{2} \mathrm{O}(1: 1)(10 \mathrm{~mL})$, was added solid $\mathrm{NaHCO}_{3}(104$ $\mathrm{mg}, 1.2 \mathrm{mmol})$ followed by acetyl chloride $(0.02 \mathrm{~mL}, 0.29 \mathrm{mmol})$. After completion of the reaction (monitored by TLC), water $(5 \mathrm{~mL})$ was added. The organic layer was separated and the aqueous layer extracted with $\mathrm{CH}_{2} \mathrm{Cl}_{2}(3 \times 15 \mathrm{~mL})$. The combined organic layer was dried over $\mathrm{Na}_{2} \mathrm{SO}_{4}$ and concentrated under reduced pressure. The crude product was purified by column chromatography over silica gel (ethyl acetate/hexane 1:6) to furnish the desired compound 2 (53 mg, 89\%)as white amorphous solid. mp $102-105{ }^{\circ} \mathrm{C}$; $[\alpha]_{\mathrm{D}}{ }^{27}+11.8$ (c 1.7, MeOH); IR (KBr): 3286, 3095, 2919, 2852, 1745, 1645, 1553, 1373, 1225, $1023 \mathrm{~cm}^{-1}$; ${ }^{1} \mathrm{H}$ NMR (300 MHz, $\left.\mathrm{CDCl}_{3}\right)$ : $\delta 5.98$ (br d, J $6.8 \mathrm{~Hz}, 1 \mathrm{H}), 4.10-3.88(\mathrm{~m}, 2 \mathrm{H}), 3.64(\mathrm{~m}, 1 \mathrm{H}), 2.74$ (br s, 1H), 1.99 (s, 3H), 1.50 $1.38(\mathrm{~m}, 2 \mathrm{H}), 1.36-1.21(\mathrm{~m}, 13 \mathrm{H}), 1.09(\mathrm{~d}, J 6.8 \mathrm{~Hz}, 3 \mathrm{H}), 0.88(\mathrm{t}, J 6.8 \mathrm{~Hz}, 3 \mathrm{H}) \mathrm{ppm} ;{ }^{13} \mathrm{C}$ NMR (75 MHz, $\mathrm{CDCl}_{3}$ ): 170.3, 74.4, 49.4, 33.5, 31.8, 29.6, 29.5, 29.2, 26.0, 25.6, 23.3, 22.6, 14.0, 13.7 ppm; HRMS (ESI) $m / z$ calcd. for $\mathrm{C}_{14} \mathrm{H}_{30} \mathrm{NO}_{2}[\mathrm{M}+\mathrm{H}]^{+} 244.22698$, found:244.22711.

\section{Acknowledgements}

The authors are thankful to the Director, CSIR-IICT, Hyderabad and Head, NPCD for their constant support and encouragement. The authors thank CSIR, New Delhi for financial support as part of XII Five Year plan programme under title ORIGIN (CSC-0108). B.T. thanks the University Grants Commission (UGC), New Delhi, India, for financial assistance in the form of research fellowship.

\section{References}

1. Cragg, G. M.; Newman, D. J. Biochim. Biophys. Acta 2013, 3670. http://dx.doi.org/10.1016/j.bbagen.2013.02.008

2. Newman, D. J.; Cragg, G. M. J. Nat. Prod. 2012, 75, 311 and references therein. http://dx.doi.org/10.1021/np200906s

3. Aiello, A.; Fattorusso, E.; Giordano, A.; Menna, M.; Navarrete, C.; Munoz, E. Tetrahedron 2009, 65,4384 .

http://dx.doi.org/10.1016/j.tet.2009.03.056

4. Aiello, A.; Fattorusso, E.; Giordano, A.; Menna, M.; Navarrete, C.; Munoz, E. Bioorg. Med. Chem. 2007, 15, 2920.

http://dx.doi.org/10.1016/j.bmc.2007.02.015

5. Koskinen, M.; Koskinen, A. M. P.; Synthesis 1998, 1075.

http://dx.doi.org/10.1055/s-1998-4494

6. Howell, A. R.; So, R. C.; Richardson, S. K. Tetrahedron 2004, 60, 11327. http://dx.doi.org/10.1016/j.tet.2004.09.056 
7. Pruett, S. T.; Bushnev, A.; Hagedorn, K.; Adiga, M.; Hynes, A. C.; Sullards, M. C.; Liotta, D. C.; Merrilli, H. M. Jr. J. Lipids Res. 2008, 49, 1621.

http://dx.doi.org/10.1194/jlr.R800012-JLR200

8. Clark, R. J.; Garson, M. J.; Hooper, J. N. A. J. Nat. Prod. 2001, 64, 1568. http://dx.doi.org/10.1021/np010246x

9. Makarieva, T. N.; Denisenko, V. A.; Stonik, V. A.; Milgrom, J. M.; Rashkes, Y. V. Tetrahedron Lett. 1989, 30, 6581.

http://dx.doi.org/10.1016/S0040-4039(01)89027-4

10. Molinski, T. F.; Makarieva, T. N.; Stonik,V. A. Angew. Chem. Int. Ed. 2000, 39, 4076. http://dx.doi.org/10.1002/1521-3773(20001117)39:22<4076::AID-ANIE4076>3.0.CO;2-D

11. Nicholas, G. M.; Hong, T. W.; Molinski, T. F.; Lerch, M. L.; Cancilla, M. T.; Lebrilla, C. B. J. Nat. Prod. 1999, 62, 1678.

http://dx.doi.org/10.1021/np990190v

12. Nicholas, G. M.; Molinski, T. F. J. Am. Chem. Soc. 2000, 122, 4011. http://dx.doi.org/10.1021/ja9942150

13. Kossuga, M. H.; Macmillan, J. B.; Rogers, E. W.; Molinski, T. F,; Nascimento, G. G. F.; Rocha, R. M.; Berlinck, R. G. S. J. Nat. Prod. 2004, 67, 1879.

http://dx.doi.org/10.1021/np049782q

14. Cuadros, R.; Garcini, E. M.; Wandosell, F.; Faircloth, G.; Fernández-Sousa, J. M.; Avila, J. Cancer Lett. 2000, 152, 23.

http://dx.doi.org/10.1016/S0304-3835(99)00428-0

15. Shaw, A. K.; Ghosal, P. Tetrahedron Lett. 2010, 51, 4140. http://dx.doi.org/10.1016/j.tetlet.2010.05.146

16. Dinda, S. K.; Das, S. K.; Panda, G. Tetrahedron 2010, 66, 9304. http://dx.doi.org/10.1016/j.tet.2010.09.018

17. Reddy, T. V. K.; Devi, B. L. A. P.; Prasad, R. B. N.; Poornima, M.; Kumar, C. G. Bio. Org. Med. Chem. Lett. 2010, 22, 4678.

http://dx.doi.org/10.1016/j.bmcl.2012.05.082

18. Clader, E. E. D.; Zaed, A. M.; Sutherland, A.; J. Org. Chem. 2013, 78, 7223. http://dx.doi.org/10.1021/jo401211j

19. Kumar, J. N,; Das, B.; Tetrahedron Lett. 2013, 54, 3865. http://dx.doi.org/10.1016/j.tetlet.2013.05.029

20. Pandey, M.; Chowdhury, P. S.; Dutta, A. K.; Kumar, P.; Pal, S. RSC Adv. 2013, 3, 15442. http://dx.doi.org/10.1039/c3ra43048k

21. Gulavita, N. K.; Scheuer, P. J. J. Org. Chem. 1989, 54, 366. http://dx.doi.org/10.1021/jo00263a019

22. Makarieve, T. N.; Denisenko, V. A.; Stonik, V. A. Tetrahedron Lett. 1989, 30, 6581. http://dx.doi.org/10.1016/S0040-4039(01)89027-4

23. Jiménez, C.; Nrews, P. J. Nat. Prod. 1990, 53, 978.

http://dx.doi.org/10.1021/np50070a033 
24. Jared-Erijman, E. A.; Bapat, C. P.; Lithgow-Bertelloni, A.; Rinehart, K. L.; Sakai, R. J. Org. Chem. 1993, 58,5732 .

http://dx.doi.org/10.1021/jo00073a036

25. Searle, P. A.; Molinski, T. F. J. Org. Chem. 1993, $58,7578$. http://dx.doi.org/10.1021/jo00078a045

26. Casapullo, A.; Fontana, A.; Cimino, G. J. Org. Chem. 1996, 61, 7415. http://dx.doi.org/10.1021/j09604200

27. Devijver, C.; Salmoun, M.; Daloze, D.; Braekman, J. C.; De Weerdt, W. H.; De Kluijver, M. J.; Gomez, R. J. Nat. Prod. 2000, 63, 978.

http://dx.doi.org/10.1021/np000081c

28. Garrido, L.; Zubia, E.; Ortega, M. J.; Naranjo, S.; Salva, J. Tetrahedron 2002, 57, 4579. http://dx.doi.org/10.1016/S0040-4020(01)00372-6

29. Clark, R. J.; Garson, M. J.; Hooper, J. N. A. J. Nat. Prod. 2001, 64, 1568. http://dx.doi.org/10.1021/np010246x

30. Zaed, A. M.; Sutherland, A. Org. Biomol. Chem. 2011, 9, 8030. http://dx.doi.org/10.1039/c1ob06060k

31. Chen, B. S.; Yang, L. H.; Ye, J. L.; Huang, T.; Ruan, Y. P.; Fu, J.; Huang, P. Q. Eur. J. Med. Chem. 2011, 46, 5480 .

http://dx.doi.org/10.1016/j.ejmech.2011.09.010

32. Liang, X.; Anders, Ch. J.; Bols, M. J. Chem. Soc. Perkin Trans. 1, 2001, 2136. http://dx.doi.org/10.1039/b101054i

33. Williams, L.; Zhang, Z.; Shao, F.; Carroll, P. J.; Joullie, M. M. Tetrahedron 1996, 52, 11673. http://dx.doi.org/10.1016/0040-4020(96)00672-2

34. Datta, A.; Kumar, J. S. R. Roy, S. Tetrahedron 2001, 57, 1169. http://dx.doi.org/10.1016/S0040-4020(00)01113-3

35. Dess, D. B.; Martin, J. C. J. Org. Chem. 1983, 48, 4155. http://dx.doi.org/10.1021/jo00170a070

36. Dess, D. B.; Martin, J. C. J. Am. Chem. Soc. 1991, 113, 7277. http://dx.doi.org/10.1021/ja00019a027

37. Martinelli, M. J.; Nayer, N. K.; Moher, E. D.; Dhonkte, U. P.; Pawlak, J. M.; Vaidyanathan, R. Org. Lett. 1999, 1, 447.

http://dx.doi.org/10.1021/o19906581

38. Tosylate compound was unstable and immediately used for the next reaction.

39. Mina, J. G.; Mosely, J. A.; Ali, H. Z.; Denny, P. W.; Steel, P. G. Org. Biomol. Chem. 2011, 9, 1823. http://dx.doi.org/10.1039/c0ob00871k 